\title{
An Analysis of Balinese Swearwords of English Private Course Students in Buleleng Regency
}

\author{
Kadek Heni Oktarina Wisudayanti \\ STKIP Agama Hindu Singaraja, Indonesia \\ kadekoktarina09@gmail.com
}

\begin{abstract}
This study is intended to find out and analyze on the Balinese swearwords that often used by the English private course students in Buleleng in their daily conversation. Due to the problems discussed, the theories suggested in this research include language definition, sociolinguistics and swearwords definition. The method applied in this research is descriptive qualitative in nature and the data are from the English private course students in Buleleng. The subjects of this research are five English course students that originally came from Buleleng and they also lived in Buleleng. Then, the data analysis is performed to search the kinds of swearwords that they used, the reason of Buleleng people using the swearwords and also how often they speak the swearwords. This study use the swearwords classification according to types of swearwords which stated by Hughes (1998). This study finds the swearwords at several term included word related to religious (pirata), word related to sex (naskleng), word from excrement (tai and bangkaan), word from name of animal (cicing and bojog), and word from mental illness (lengeh,and buduh). Altough those words are dirty or rude to be said, but it often used by the Buleleng people even from the children until the adult. It will still like that for the next many years, because that is their culture herritage from many years ago.
\end{abstract}

Keywords: Language; Sociolinguistics; Swearwords; Balinese Swearwords.

\section{INTRODUCTION}

Language has a function to make a relationship with other people. It is supported by Wardhaugh (1986) as follows "Language is what the member of a particular society speak". The quotation above implies that language has a function to make a relationship with other people. Language is primarily spoken, although it can be transferred to other media such as writing (Wiradnyana, 2012). There is one language which becomes and international language, namely English language. English language is used as an international language communication among the people in the world which come from different countries, cultures and language background. This study focuses on the way people use language to express social class, group status, gender, or ethnicity, and it looks at how they make choices about the form of language they use. Sociolinguistics constituent the annexation from two word that are the word socio and linguistic (Nababan,1993 as cited in Amelia,2015). Sociolinguistics studies the relationship between language and society and identifies the social function of language. According to Holmes (1992), stated that sociolinguistics studies the 
relationship between language and society. In this case the sociolinguistic will identifying the social function of language and the ways it is used to convey the meaning.

Holmes (1992) also explains sociolinguistics aspect that consist of participant (social distance and social status), the background (place and time), the topic, and the function. First, the participants are influence by social distance and social status. Social distance refers to how we know the addressee, this is the important factor that determines how we speak to them (Wiradnyana, 2012). Meanwhile, social status relates to the position of someone in the society. In the communication, people speak using their own language that show the social status of speaker itself. Second aspect is background. The background shows the context from the event like place and time from the interaction. And the last aspect is topic and function. In the communication, people should know about the function and topic of the conversation that influence to the choices of language form. Based on that information, it can be concluded that sociolinguistic is study the relation between language and society which is related to participant of the language However, there are some languages which are so taboo and became a bad language for communication which is called swearword. There are many kinds of swearwords that exist in every language. In English language, people often hear the swearwords such as shit, fuck, damn it or nuts. The example of swearwords in Indonesia language such as bajingan, bangsat, anjing, etc. Swearwords are fascinating. Society condemns them, few admit to use them, and still, everybody swears, at least occasionally. Swearwords are a natural part of our language, and they are undoubtedly one of the most efficient ways to do away with extra frustration or anger in difficult situations. It has even been suggested that swearwords may be a factor in reducing stress (Crystal, 1995).

Swearword is one of language grow in our community. According Anderson \& Trudgill (1990) define swearword as reference to something taboo in given culture, to be interpreted and used to express strong emotions and attitudes. In addition, Robin (1992) stated that swearword often found in the words that are used to convey anger, passion, etc. Based on those definition, swearword can define as the taboo word used by certain people to express their feeling in the community. According to Hughes (1998) as cited in Wiradnyana (2012), there are several varieties of swearword in the community. First, swearword can be explained word related to sex. The swearword dealing with sexuality becomes the largest source in using words. In sexual term, there are genital and anatomical source of swearword. For genital, the example is "prick, pillock (male genital), cunt, and twat (female genital). In anatomical term, there is "asshole".Second, swearword explain as a word from excrement. There are several words of excrement include shit, piss, turd, fart, and crap. And the last, swearword identify word from name of animal. Actually, the name of animal is not taboo at all. However, if they are uttered or refer to the person, they may be considered as swearword. The swearwords in these terms are the animal categorized weak, disguiting, beast or any other displeasure criterions such as: "cow, swine pig " (Hughes, 1998)

In Bali itself; especially in North Bali or Buleleng regency there is many swearwords which heard by us every time. Swearwords are common language in Buleleng. Many people in Buleleng speak the swearwords fluently. Those words are not used to express bad feeling but it always used in every conversation 
between the people in north Bali. The word such as "pirate", is often spoken by the Buleleng people. This example is one of many swearwords which are understood and used by the Buleleng people. In the human minds, those swearwords are not politely used in daily conversation. The use of those words can make the people offended one and each other. However, it does not happen in Buleleng. It is because of people intimate with those kinds of languages. Moreover, the uses of swearwords in Buleleng are welcome in order to make a good relation with many friends. It can be seen in the use of word "cicing". This word "cicing" is usually use to call somebody in order to get his/her interest. The sentence can be like "cicinge kar kije kone bint?". The words "cicing" means dog. In other word, we call our friends same we call as a dog. It is really rude, because human is more perfect than animal. Actually, friend that we called by using that word is fine He/she doesn't matter about that word. Unfortunately, the use of such that word cannot be accepted in other place except Buleleng.

The use of swearwords in Buleleng cannot be separated from the history of Buleleng itself. According to I Made Pageh, as stated in Balipost 25 February 2006, the original Buleleng people did the rebellion to the government. They were rebelled to the king who used his dominance to hurt the people below his case. They were rebelled the use of the language among the Buleleng people. The language that used at that time was the subtle language (sor singgih) which according to them the subtle language could differentiate between the caste people and the original people. The people at that time which had educated think that they should did something to change their life. So that, the rebel through the language at that time was done in areas inhabited by educated people like teachers. I Made Pageh also said that in order to continue the rebellion, the Buleleng people began to use the swearwords in everyday conversation. This language became a democratic language which was used to interact with other people even they came from the highest caste. The aim of the rebellion still exists until now. It is shown in how they communicate in daily life with using the swearwords. They do not care if someday that they are talking to someone from the highest caste. That's how the Buleleng's language is the unique language in Bali and it is different in any language in other region in Bali. That is why we should know their habit on order to make a good conversation. Besides that, if we know that we will not be angry with them while they are using the swearwords.

The applications of swearwords are common in Buleleng. It is also spoken by the students in Buleleng. In order to know whether the students of Senior High School speak the swearwords, the researcher did this research among several students who are originally from Buleleng. In this research, the researcher tries to know about the swearwords that they speak. The frequency of those swearwords used and the reason why they speak those dirty words. While doing this research, the researcher found that those students used the swearwords because it may make them feel intimate with each other. Besides that, many of them said the use of the swearwords make them enjoy when the all talking with their friends. Therefore, in order to know the kinds of swearwords, the frequency of the use of the swearwords, and the reason why the students use the swearwords, the researcher does this research. It did also need many helps from several students that must be original from Buleleng to solve this problem. 


\section{METHOD}

This research is a descriptive qualitative research design. This design was used to describe phenomenon occured in society. Sutrisno Hadi asserts "descriptive method is a kind of method which is conducted by collecting and analyzing the data and drawing the conclusion without making generalization" (1986). Further, Saiffudin Azwar states that descriptive analysis aims to give a description about subject that is being researched based on the given variables from the group of research subject and it is not intended to examine the hypothesis (2001). The research intends to describe the swearwords used by the northern Balinese people and how to use it in everyday life. The data of this research are taken from observation and interview method. The researcher used those methods to collect the authentic data from the subjects. In this research, the data that the researcher wanted was the swearwords which were used by the Buleleng people. The subjects of the study were five English course students that originally came from Buleleng and they also lived in Buleleng. The data of this research are taken from to describe the swearwords used by the five students in Buleleng. the researcher was analyzing the conversation and used conversation and interaction analysis. Conversation and interaction analysis is close to other method of analysis which focus on language and production of meanings. As their data, this study used audio recordings made from naturally occuring interaction.

\section{FINDINGS \& DISCUSSIONS}

This study finds the 8 items of swearwords that used by the English course students who were originally came form Buleleng. All of the items will be classified based on the types of swearwords by Hughes (1986).

Table 1. Swearwords Classification and the Meaning

\begin{tabular}{llll} 
No & Types of Swearwords & The terms & The meaning \\
\hline 1 & Words related to religious & Pirate & Ancestors \\
\hline 2 & Word related to sex & Naskleng/kleng & Male genital \\
\hline 3 & Word from excrement & Tai & Feces \\
\hline 4 & Word from name of & Cicing & Dog \\
& animal & Bojog & Monkey \\
\hline 5 & Word from mental illness & Lengeh & Stupid \\
& & Buduh & Crazy \\
\hline
\end{tabular}

As had been asserted previously, researcher found 8 items of swearword used by 5 children who were originally from Buleleng. All of them will be explained one by one as bellow:

a. Words related to religious

Word related to religious is the swearwords that contain several words which are related to the religion.

Swearwords Meaning 
Pirate - Ancestors

A1. Pirate

Pirate or in English we called ancestors of human being is a great grandparents who was dead in long time ago. It was used to express the dissatisfaction with someone or something.

A. 1

Setting : Agus's house

Subjects : : Agus, Yuda and researcher

Topic : Handphone

Agus and Yuda were talking about Agus toys. When yuda asked whether Agus mother bought a new laptop for Surya or not, Surya looked piqued. The conversation that happened can be seen as follows.

Agus : da uling dje cai? Mare ci teke! (where have you been Yuda? You come late!)

Yuda : ake mare bangun nani! (I just wake up by now!)

Agus : tong jelemane males gati jlemanene (you're so lazy man)

Yuda : cing, ake tumben the megadang! (this is the ist time I stay up night. dog!)

Agus : beh tumben. Nani be ngewai keto tumben misi ngoraang! (are yous sure? I know, You do it every night!)

Yuda : nani be patuh teh. (you do the same too).

Agus : patuh ngujang nani? Patuh tetehan? (what is the same? Same drool?)

Yuda : cicilange ape Tong Handphone!

b. Words related to sex

Word related to sex is the swearwords that contain several words which are related to the

genital and anatomical of human being.

Swearwords Meaning

- $\quad$ Naskleng - $\quad$ Male genitals

B.1 Naskleng or kleng

Naskleng was Balinese word for dick. It was used to express dissatisfaction with something or someone else.

B.1

Setting : Agus's house

Subects : Agus, Yuda

Topic : : lempog "Balinese snack"

Surya, Yuda and the researcher were talking about the lempog or Balinese snack that was bought by Yuda. Surya felt disappointed because the amount of the lempg was not too many. Although Surya was disappointed, but he realized that it was his fault when he gave few money to Yuda. Those conversations are:

Agus : be payu meli lempog da? (have you buy lempog Yuda?) 
Yuda : ube ne ape. (Yes, this is it.)

Agus : mimih, ape ney? (Wow, what is this?)

Yuda : Naskleng lengeh gati cai gus. Ne be madan lempog.

In addition be used to express disappointment, the word naskleng is also used to express the surprise feeling. The example is:

B3

Setting : Agus's house

Subjects : Agus and Yuda

Topic : : Yuda got much money

Surya and Yuda were talking about the money that Yuda collected to bought some drinks. From some friends, Yuda could collect much money, so he felt that he would be rich with the money.

Yuda: naskleng, ake sugih perjanian ney. Mai beliang capcin alu. (I will rich now, dick. Let us buy capcin.)

Agus : Nah da, ajum gati. ( Ok Yuda, you're so arrogant.)

In this discussion, the researcher analyzed the swearword used by the students in English course. The swear word found at several term included word related to religious (pirata), word related to sex (naskleng), word from excrement (tai and bangkaan), word from name of animal (cicing and bojog), and word from mental illness (lengeh,and buduh). In the first word "pirate", it seen on conversation:

Agus : cicilange ape? Tong piratene!

Yuda : ne hp ( this is new hand phone)

Agus : tusing not, nyilih ake ney ( oh no, I just borrow it)

The pirate itself was addressed to the person who slanderous to Agus. Agus swore by using that word to express his anger to the person who said that surya's mother bought new hand phone for him. The next conversation was about the conversation between Yuda and Surya. The researcher saw the students used the word "naskleng" in the conversation

Agus : mimih ape ney? (what this is?)

Yuda : naskleng lengeh gati cai .. ne be madan lempog ( You're so stupid, this is lempog)

Based on those conversation, Agus used swearword "naskleng" to express his disappointed with the lempog or Balinese snack that Yuda bought. Besides, the swearword "naskleng" also used to express the surprise feeling. Here the conversation between Agus and Yuda.

Yuda : naskleng, ake sugih jani. Mai beliange capcin alu ( I am rich. Lets buy capcin)

Agus : nah da, ajum ti (Ok da, you're so arrogant) 
From the conversation above showed that Yuda had a lot of money. So the swear word naskleng used to express happy feeling. In the conversation, Yuda wants to bought capcin to Agus. The next swearword is tai, this word relate to the excrement, thus word found on the conversation between Bayu and Surya.

Bayu : Sur lung ti gantungan kuncine. (You have a nice key hanger ,sur) Surya : tai, dong ake ne ngelah (it's not mine). Gantungan kuncinya di motor mio bukan vario. (the key hanger on mio not vario)

Based on those conversation, the word tai showing their bad feeling about something. We saw there were some people used the word tai in the Buleleng regency. In the conversation, Surya used that word because he saw bayu wrong take the key hanger.In addition, the other swearword to excrement is bangkaan that showed in the conversation between Surya and Bayu.

Surya : ape ci gae yu? (what are you doing yu?)

Bayu : ne ake ngambar dibuku ci'ne (I draw some picture on your book) Surya : bangkaan, hapus jani (you dead man, erase it now)

In the conversation above Surya used swearword because he anger to Bayu. Bayu drew some picture on Surya book. So, Surya express their feeling by used swearword.The researcher also analyzed the swearword that related to the animal in the conversation between Tini and Surya. Here the conversation

Tini : Liu ci ngelah pis o, idih pise (You have a lot of many, give your money)

Surya : cicinge ne matre gati, memene idihin ( you' re so materialism, ask your mom )

In the conversation, surya used the word cicing not to mock somebody, but he used to express his anger to his friend. Surya used those word because Tini asked Surya to gave his money. The last swearword that found by the researcher is bojog in the conversation between Yuda and Agus

Yuda : Jani be sing taen berhubungan bin, ( I never communication with him)

Agus : de bin runguage bojoge to, ake yen ngelah timpal keto be ketendang ( don't care with those monkey, if I have a friend like that, I will kick him)

Based on those conversation, Agus used the word bojog because he feel angry with Yuda friend. Besides, Agus also feel empathy with Yuda because he got a bad friend in their life. The word lengeh is the swearwords that related to mental illness.

Yuda : tawang cang to, men adi care buduh fotone ( yes, i know, but you looks like crazy)

Tini : to be suud pentas da. (it have been finishing da)

Yuda : tutup nake lengeh, nani ngae comment di foto ake ne (just shut it, stupid. You must be write comment in my photo) 
From the conversation above, Yuda was used the swearwords lengeh to show his disappointment to Tini because Yuda thought that Tini was not respect his privacy. Lengeh or stupid was spoken by Yuda in order to warned Tini about something that is wrote by Tini in Yuda's comment of instagram. Those swearwords are used by the students when they talk with their friends. This always heard every time when you meet some students in the age between 11-12 years old do the conversation. They always use such kind of the swearwords in every sentence that they speak. They will never use those words in their home altough they feel angry with their parents. Beside that, they never used those swearwords to talk with the older man or somebody that they do not know before. It is because they feel intimate with their friends so that they used those swearwords when they have a conversation. Based on the questions that researcher had asked to the speakers, there is some interested point to be discussed. Here, most of the speaker said that they used those words to express his anger or disappointed with someone. Moreover, people did not only use those swearing words to express the anger or the disappointment to someone or something. In addition, swearing word also used to express happiness, surprise or antagonism. About the function, most of those swearing words were as a commisive. This particularly because all of people sworn to express their feeling to another people. But, there was one different function. The function was called acknowledgement. Here, the function was only to great someone by using word.

\section{CONCLUSION}

The result of the current study concluded that vocabulary is important points in language learning process. Teachers are required to use effective strategies in order to help students enrich their vocabulary. Strategies used by teachers should be fun, encouraging and motivating students. Using interactive media such as pictures, games and songs had been studied to be beneficial in creating positive learning environment and fun ways of learning.

\section{REFERENCES}

Amelia,S. (2015). Review of literature. Retrieved from http://repository.usu.ac.id/bitstream/123456789/49536/3/Chapter\%20II.p $\underline{\mathrm{df}}$

Andersson, L\& Trudgill, P. (1990).Bad Language.Oxford: Basil Blackwell.Ltd.

Crystal, David. (1995). The Cambridge Encyclopedia of the English Language. Cambridge: Cambridge University Press

Holmes, J. (1992). An Introduction to Sociolinguistics. London :Longman

Saiffudin Azwar. (2001). Metode Penelitian. Yogyakarta: Pustaka Pelajar.

Sutrisno Hadi. (1986). Metodologi Research. Yogyakarta: Yayasan Penerbitan Fakultas Psikologi Universitas Gadjah Mada Yogyakarta.

Wardhaugh. Ronald. (1986). An Introduction to Sociolinguistics. USA: Basil Blackwell Ltd http://www.britannica.com/topic/language

Wiradnyana, P. E. (2012). An Analysis of Balinese Swearword among th Northern Balinese Senior High School Students in Their Daily Conversation. ( A Sociolinguistics Study). 